OC.

101.60/4:

121

Iechnical Report 1121

\title{
Question Generation as a Learning Multiplier in Distributed Learning Environments
}

\author{
Arthur C. Graesser \\ University of Memphis \\ Consortium Research Fellows Program \\ Robert A. Wisher \\ U.S. Army Research Institute
}

October 2001

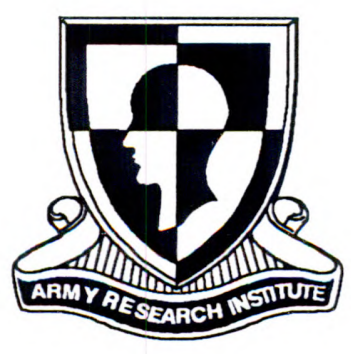

United States Army Research Institute for the Behavioral and Social Sciences

Approved for public release; distribution is unlimited.

US Govt. Document

Nondepository

SEP 112002

University of Illinois

At Urbana-Champaign 